\title{
ISLAM AND (POLITICAL) LIBERALISM A Note on An Evolving Debate in Indonesia
}

\author{
Supriyanto Abdi \\ The Asia Institute, the University of Melbourne, Australia
}

\begin{abstract}
This paper is divided into three parts. The first part will provide a general overview of some major approaches in the discussion on the relationship between Islam and liberalism. Following this, the next section will briefly elaborate Talal Asad's notion of Islam as 'a discursive tradition' and John Rawls' distinction between liberalism and political liberalism and how they might contribute to the discussion on the relationship between Islam and liberalism. In the final part, the paper will then present a general observation on the evolving encounter between Islam and liberalism in Indonesia and the accompanying debate over this encounter among major Islamic groups in the country. In doing so, it will be argued that while liberalism as a comprehensive doctrine has been, and will remain, contested among Indonesan Muslims, there has been a growing support among them for 'political liberalism', although not in a purely Ralwsian sense.
\end{abstract}

Keywords: Islam, liberalism, Indonesian Muslim.

\section{Introduction: Rethinking Islam and Liberalism}

There are many approaches adopted by scholars in discussing the relationship between Islam and liberalism. Two approaches, however, seem to be dominant. The first approach centers on what is assumed to be the basic values and traditions of both Islam and liberalism and the degree to which they are compatible. Two main perspectives emerge from this approach. The first is what might be called as 'univocal' perspective and the second is what is described as 'multivocal' perspective. While the first approach focuses its scope of analysis on the importance of religious tradition and sacred text, the second approach is based more on human agency and context rather 
than foundational texts or basic tenets of tradition. Scholars subscribing to the second approach acknowledge in varying degrees the contingent relationship between, 'texts', human agency and changing historical socio-political context.

On the other hand, scholars using a 'univocal' perspective tend to define Islam as a fixed and unitary entity. This fixed and monolithic entity is construed as either essentially compatible or incompatible with liberalism. The proponents of this perspective, however, mostly point to and argue for the latter. In this perspective, Islam is thus understood to be inherently incompatible or having basic problems with Western ideals and ideologies, including liberalism. Bernard Lewis, Samuel Huntington, and Francis Fukuyama are widely associated with this perspective. Lewis, for example, suggests that Muslims have a deeply rooted hatred toward the West and this hatred "goes beyond hostility to specific interests or actions or policies or even countries and becomes a rejection of Western civilizations as such, not only what it does but what it is." Echoing Lewis, Huntington also famously claims that "the underlying problem for the West is not Islamic fundamentalism. It is Islam." In a similar vein, Fukuyama argues that Islam is "one major world culture that arguably does have some very basic problems with modernity." 3

In contrast to this 'univocal' perspective, 'multivocal' perspective shows and emphasizes the diversity within Islamic tradition, some of which are hospitable to and compatible with liberal political values. For this perspective, Islam, like any other religious traditions, provides doctrinal and institutional sources for both liberal and illiberal or nonliberal political discourse and culture. Alfred Stepan, among others, is the main proponent of this perspective. On the question of the relationship between non-Western religions and democracy and what he calls as 'twin toleration', Stepan argues that "it is appropriate not to assume the univocality, but to explore whether these traditions contain

\footnotetext{
${ }^{1}$ Bernard Lewis, "The Roots of Muslim Rage: Why so many Muslims deeply resent the West, and why their bitterness will not easily be mollified," Atlantic Monthly, September 1990. Available online at: http://www.theatlantic.com/issues/90sept/rage.htm.

2 Samuel P. Huntington, The Clash of Civilizations and the Remaking of World Order (New York: Simon and Schuster, 1996), p. 217

${ }^{3}$ Francis Fukuyama, "History and September 11," in Ken Booth and Tim Dunne (eds.), Worlds in Collision: Terror and the Future of Global Order (New York: Palgrave McMillan, 2002), pp. 31-32
} 
the multivocal components that are usable for (or at least compatible) with the political construction of twin tolerations." 4

Univocal perspective has been increasingly challenged and criticised for its essentialist and totalizing premises. The main problem of this perspective, as its critics argue, is its reductive reference to Islam as a surrogate idea or usage for unitary faith, history, or socioeconomic condition. ${ }^{5}$ It is thus discredited for having failed to capture the complex nature of religious movements and ignoring the intimate relationship between religious discourses and different and changing socio-political contexts. Edward Said, one of the most prominent critics of Orientalism, pejoratively illustrates this kind of perspective as expending "thousands of words without a single reference to people, periods, and events." 6

Multivocal perspective, on the other hand, has been more widely accepted. It is not, however, without problems. While it is praised for moving away from essentialist and totalizing tendencies, it has little to say on how certain discourses are at times and in different contexts dominant or hegemonic within particular religious traditions. In other words, while it acknowledges the possibility of compatibility between (some of) religious traditions and 'secular' ideas, it still fails to ascertain whether and and in what condition these compatible religous discourses prevail and come into dominance. ${ }^{7}$ It is here that a historical and contextual approach has more explanatory power.

According to the latter perspective, Muslim discourses and the actors who articulate them are historically situated. The scripture or religious texts should not be used to attribute homogeneity to Muslim

\footnotetext{
${ }^{4}$ Alfred Stepan, "Religion, Democracy and 'Twin Toleration'," Journal of Democracy, 11, 4 (October 2000), p. 44.

${ }^{5}$ Critical accounts of essentialist perspective can be found, among others, in Aziz AlAzmeh, Islams and Modernities (London, New York: Verso, 1993); John L. Esposito and John A. Voll, Islam and Democracy (New York and Oxford: Oxford University Press, 1996); Fred Halliday, Islam and the Myth of Confrontation: Religion and Politics in the Middle East (London: IB Tauris, 2003); Amyin B. Sajoo (ed.), Civil Society in the Muslim World: Contemporary Perspectives (London: IB Tauris, 2002); Salwa Ismail, Rethinking Islamist Politics, Culture, the State and Islamism (London: IB Tauris, 2003)

${ }^{6}$ Edward Said, "Scholars, Media and the Middle East," in G. Viswanathan (ed.), Power, Politics, and Culture: Interviews with Edward Said (New York: 2001), p. 297.

7 See John Anderson, "Does God Matter, and If So Whose God?: Religion and Democratization," Democratization, 14, 4 (August 2007), p. 193.
} 
societies since they are subject to competing readings and defined by and large according to their social existence. ${ }^{8}$ As a result, their insertion into particular contexts with different power relations results in "a multitude of discourses that must be accounted for reference to the power position at stake." Muslim political discourses in other words are "part of changing institutions, and discourses which can be, and often are, contested and reconstituted." 10 The highly essentialist claims such as the clash of civilizations suggested by Huntington thus "only serve to obfuscate the real dynamics of the struggle between interpretative communities over who gets to speak for Islam and how."11

\section{Islam as 'A Discursive Tradition'}

Central to the understanding of Muslim discourse as explained above is Talal Asad's notion of Islam as 'a discursive tradition'. Collapsing the binary opposition between tradition and modernity, Asad affirms the significance of tradition as a meaningful and binding relationship and orientation of the present (and future) to the past. ${ }^{12}$ Far from being a past-oriented, a discursive tradition as defined by Asad has a dynamic relationship with

"a past (when the authentic practice was instituted) and a future (how a correct performance and its fruits can be secured in future) through a present (how it is linked to other practices, institutions, and social conditions)." "13

The Islamic discursive tradition is therefore understood as a "historically evolving set of discourses, embodied in the practices and institutions of Islamic societies and hence deeply imbricated in the

\footnotetext{
${ }^{8}$ See Asef Bayat, Making Islam Democratic: Social Movements and the Post-Islamist Turn (Stanford, California: Stanford University Press, 2007)

${ }^{9}$ Salwa Ismail, Islamist Politics, Culture, the State and Islamism (London: IB Tauris, 2003), pp. 16-7.

${ }^{10}$ See Talal Asad, "Ideology, Class and the Origin of the Islamic State," Economy and Society, 9, 4 (November 1980), p. 467.

${ }^{11}$ Khaled Abou el-Fadl, "The Orphan of Modernity and the Clash of Civilizations," Global Dialogue, 4, 2 (Spring 2002).

12 Ovamir Anjum, "Islam as A Discursive Tradition: Talal Asad and His Interlocutors," Comparative Studies of South Asia, Africa and the Middle East, Vol. 27, No.3 (2007), p. 661.

${ }^{13}$ Ibid.
} 
material life of those inhabiting them." 14 Defined as such, the Islamic discursive tradition is far from a systemic homogeneity. Instead, it is characterized by debates, disagreements and contestations. ${ }^{15}$

Closely related to the idea of Islam as a discursive tradition is the concept of 'orthodoxy'. While Asad does acknowledges orthodoxy, his use of this term is very different from the invocation of the same term by most Orientalists and anthropologists. As he notes,

"Orthodoxy is crucial to all Islamic traditions. But the sense in which I use this term must be distinguished from the sense given to it by most orientalists and anthropologists. Anthropologists like El-Zein, who wish to deny any special significance to orthodoxy, and those like Gellner, who see it as a specific set of doctrines "at the heart of Islam," both are missing something vital: that orthodoxy is not a mere body of opinion but a distinctive relationship - a relationship of power. Wherever Muslims have the power to regulate, uphold, require, or adjust correct practices, and to condemn, exclude, undermine or replace incorrect ones, there is the domain of orthodoxy." 16

The idea of Islam as 'a discursive tradition' as defined by Asad above is an important contribution to the discussion on Islam and its relationship with other traditions, including liberalism. There are three reasons for this. First, it locates the multivocality of Islam within certain shared point of reference, avoiding both the essentialization and extreme relativization of Islam. Second, it emphasizes the contested nature of Islamic discourse and the working of certain power relation within it; and third, while it acknowledges the role of human agency as the interpreters of the texts, it also stresses the constraining power of the discursive tradition itself.

\section{Liberalism and Political Liberalism}

Political philosophers often speak of two forms of liberalism: comprehensive liberalism and political liberalism. The first is a way of

\footnotetext{
14 Ovamir Anjum, "Islam as A Discursive Tradition: Talal Asad and His Interlocutors," p. 661

15 Sean McLoughlin, "Islam(s) in Context: Orientalism and the Anthropology of Muslim Societies and Cultures," Journal of Beliefs \& Values, 28, 3 (December 2007), pp. 273-296.

16 Talal Asad, “The Idea of Anthropology of Islam,” pp. 15-6.
} 
life, a theory of value, and an epistemology. ${ }^{17}$ The latter, by contrast, is purely a doctrine of social and political cooperation. It seeks to elaborate "the most reasonable public conception of justice and citizenship for free and equal persons, given the existence of disagreement on the ultimate meaning of life and the epistemological foundation for discovering it." 18

John Rawls has over the years become one of main contributors to the conceptualization of political liberalism and its differentiation from comprehensive liberalism. Rawls makes the distinction between comprehensive moral and philosophical doctrines, on the one hand, and his conceptions limited to "the political" on the other. The underlying concern of his conceptualization of political liberalism is formulated in the following question:

"How is it possible that there may exist over time a stable and just society of free and equal citizens profoundly divided by reasonable though incompatible religions, philosophical, and moral doctrines?"19

Political liberalism, as a political conception of justice, is basically Rawls' answer to this question. Rawls acknowledges that comprehensive religious or moral doctrines of "the good" - such as Islam, liberalism and socialism -are necessarily incompatible as a matter of philosophical truth. Nevertheless, despite their irreconcilable philosophical differences, adherents of conflicting comprehensive doctrines may agree with, and build, what he calls "overlapping

\footnotetext{
${ }^{17}$ Scholars have competing claims as to whether liberalism constitute a single, coherent project. Jeffrey Stout, for example, dismisses the unifying notion of a single liberal project arguing that liberalism should be the "name for a particular kind of obsolete ideology whose critics and defenders thought there was something worth calling the liberal project and who therefore engaged in fruitless debates over whether it was a good or bad thing. Others, such as Talal Asad, on the other hand, have argued for the unifying and common political and moral language of liberalism despite the tension inherent to it. See Jeffrey Stout, Democracy and Tradition (Princeton: Princeton University Press, 2004) and Talal Asad, Formation of Secular: Christianity, Islam, Modernity (Stanford: Stanford University Press, 2003)

18 Andrey F. March, "The Demands of Citizenship: Translating Political Liberalism into the Language of Islam," Journal of Muslim Minority Affairs, Vol. 25, No. 3 (December 2005), p. 401.

${ }^{19}$ John Rawls, Political Liberalism: Expanded Edition (New York: Columbia University Press, 2005), p. xvi
} 
consensus" on certain fundamental points related to political organizations and social cooperation. ${ }^{20}$

Rawls thus advances his political liberalism with a practical aim. "It presents itself as a conception of justice that may be shared by citizens as a basis of a reasoned, informed, and willing political agreement". ${ }^{21}$ But for this to happen, Rawls argues, it should be, as far as possible, "independent of the opposing and conflicting philosophical and religious doctrines that citizens affirm." 22 The political conception of justice, as a result, is "formally and functionally impartial, seeking to neither advance nor diminish any single comprehensive doctrine." 23

With this 'neutral' normative position, Rawls' political liberalism could be considered as more hospitable to religious traditions and the coexistence between the two is theoretically more possible. Some scholars, however, show that Ralws' political liberalism still does not escape from certain liberal biases and preferences. Bowen, for example, suggests that intuition about North American institutions and sensibilities, in which values of individual autonomy and equality might be presumed to predominate, is discernible in Rawls's formulation of justice. ${ }^{24}$ In a similar vein, Bhikhu Parekh argues that liberal doctrine of valuing autonomy and "the good life" are outcomes of a particular Western intellectual and social history, in which Greek philosophy, Christianity, and colonialism each contributed. ${ }^{25}$ Considering this social, historical and normative aspects of political liberalism, one can argue that its applicability in the contexts other than Western and advanced democracies might be limited. ${ }^{26}$ In fact, Rawls' conception

${ }^{20}$ Mohammad Fadel, "The True, the Good and the Reasonable: the Theological and Ethical Roots of Public Reason in Islamic Law," Research Paper, University of Toronto Legal Studies Series (2007), pp. 4-5.

${ }^{21}$ Rawls, Political Liberalism, p. 9.

22 Ibid.

${ }^{23}$ Khaled A. Beydoun, "Laicite, Liberalism and the Headscarf," Journal of Islamic Law and Culture, 10, 2, Month (2008), p. 194.

24 John R. Bowen, Islam, Law and Equality: An Anthropology of Public Reasoning (Cambridge University Press, 2003), p. 11.

${ }^{25}$ Bhikhu Parekh, Rethinking Multiculturalism: Cultural Diversity and Political Theory (Basingstoke: Macmillan, 2000).

${ }^{26}$ Mehmet Fevzi Bilgin, "The Prospect for Political Liberalism in Non-Western Societies," Critical Review of International Social and Political Philosophy, 10, 3 (September 2007), p. 375. 
and its application are so specific to the United States that they may not easily resonates with other societies, especially postcolonial Islamist societies in Africa and Asia. ${ }^{27}$

Another aspect of Rawls' political liberalism which might be also problematic is his notion of "public reason". ${ }^{28}$ Rawls distinguishes between the scope of public reason and what he calls the "background culture" of civil society, which includes such associations as churches, universities and the like. ${ }^{29}$ According to Rawls, citizens have the right to ground their views in their comprehensive doctrines or broad worldviews, like religion, morality, or philosophy, but such doctrines should be presented as public reason. While he still considers the possibility of invoking comprehensive doctrines in public life, he limits this possibility in the ways that strengthen the ideal of public reason itself. ${ }^{30}$ For this reason, some assert that Rawls' public reason is clearly liberal in character and hence refer to it as a liberal public reason. ${ }^{31}$

One main problem with this liberal public reason is its tendency to ignore the complex and contingent relationship between religion and politics. As Asad reminds us, religion and politics has always been involved in the world of power, and that "the categories of 'politics' and 'religion' turn to implicate each other more profoundly than we thought". ${ }^{32}$ As he explains:

"While the modern idea of a secular society involves a distinctive relation between state law and personal morality, with the result their religion becomes a matter of (private)

\footnotetext{
27 Abdullahi Ahmed An-Na'im, Islam and the Secular State: Negotiating the Future of Shari'a (Cambridge, Mass: Harvard University Press, 2008), p. 101.

${ }^{28}$ Rawls, Political Liberalism, pp. 212-254.

${ }^{29}$ Ibid., 443

${ }^{30}$ Ibid. According to Rawls, the proper domain of public reason is the "public political forum," which provides for three different discourses to take place: "the discourse of judges in their decisions, and especially of the judges of a supreme court; the discourse of government officials, especially chief executives and legislators; and finally, the discourse of candidates for public office and their campaign managers, especially in their public oratory, party platforms, and political statements." See Rawls, Political Liberalism, p. 443.

${ }^{31}$ Raja Bahlul, "Toward Islamic Conception of Public Reason," Journal Islamic Law and Society, 12, 1 (Spring 2003), p. 56.

32 Talal Asad, Formation of Secular: Christianity, Islam, Modernity (Stanford: Stanford University Press, 2003).
} 
belief, its translation into a legal right the individual's ability to express and practice his or her beliefs freely brings 'religion' back into the public domain".

\section{Islam and Liberalism in Indonesia: An Evolving Discourse}

Despite the fact that Muslims are a huge majority in Indonesia, the country has been from its inception, and still is, a 'secular' state. Having played an important role in anti-colonial resistance since the very beginning of the nationalist movements, Islam nevertheless was excluded from the framework of Indonesian nationhood and a more 'secular' state ideology, Pancasila, was chosen by postcolonial Indonesian leaders as the foundation of the newly born nation. ${ }^{33}$ Proposals and attempts to officially establish link between Islam and the state has frequently failed for the lack of popular and political support. ${ }^{34}$

Secular-nationalist-oriented Indonesian nationhood has then dominated political discourse and practice in the country for most of its history. As with Marxism, Islamism has been discursively and constitutionally marginalized from the state power and ideology. During the Soekarno era and at least the first two decades of Soeharto's regime, political Islam has never been let to dominate national politics and political organizations committed to explicitly Islamic goals have never been able to attract sufficient popular support. ${ }^{35}$

This general historical and political context and the New Order's repression on political and ideological Islam in the first two decades of his rule had a significant impact on the development of Islamic political discourse in the country. Since the late 1970s and early 1980s, scholars on Indonesian Islam have noticed the emergence of a 'new' Islamic thinking which is liberal and progressive in character among certain Muslim intellectuals. Identified variously by different scholars

\footnotetext{
${ }^{33}$ Robert W. Hefner, "Islam in an Era of Nation-States: Politic and Religious Renewal in Muslim Southeast Asia," in Robert W. Hefner and Patricia Horvatich (eds), Politics and Religious Renewal in Muslim Southeast Asia (University of Hawai'i Press: Honolulu, 1997), p. 21.

${ }^{34}$ Ibid., p. 122.

35 See Robert W. Hefner, "Islam and Nation in the Post-Soeharto Era," in Adam Schwartz and Jonathan Paris (eds), The Politics of Post-Soeharto Indonesia (Council on Foreign Relation Press: New York, 1999).
} 
as "Islamic neo-modernism", 36 "civil Islam",37 "cultural Islam", 38 "liberal Islam" or "progressive Islam", 39 this new Islamic thinking consistently claims that "the modern ideals of equality, freedom, and democracy are not uniquely Western values, but modern necessities compatible with, and even required by, Muslim ideals". ${ }^{40}$ This stream of Islamic thinking has spontaneously developed in both "traditionalist" circle and "modernist" camp. ${ }^{41}$

From a comparative Islamic perspective, the degree to which Indonesian Muslim intellectuals are engaged with modern ideas such as democracy, pluralism, human rights and civil society is remarkable. As Hefner notes, instead of secular nationalists, it is reform-minded Muslim intellectuals "who have been the largest audience and supporters for democratic and pluralist ideas in Indonesia since the 1980s." 42 He even suggests that "nowhere in the Muslim world have Muslim intellectuals engaged ideas of democracy, human rights, pluralism, civil society and the rule of law with a vigour and confidence equal to that of Indonesian Muslims." 43 Another scholar affirms Hefner's assertion suggesting that Islamic liberalism "has imprinted itself, not only on Islamic discourse, but also on the general national discourse." 44

\footnotetext{
${ }^{36}$ Greg Barton, "The Impact of Neo-Modernism on Indonesian Islamic Thought: The Emergence of a New Pluralism," in David Bourchier and John Legge (eds), Democracy in Indonesia: 1950s and 1990s (Clayton: Centre of Southeast Asian Studies, Monash University), pp. 143-50.

37 Robert W. Hefner, Civil Islam: Muslims and Democratization in Indonesia (Princeton University Press: Princeton and Oxford, 2000), p. 216.

38 Greg Fealy, "Islamisation and Politics in Southeast Asia: the Constrasting Cases of Malaysia and Indonesia", in Nelly Laboud and Anthony H. Johns (eds), Islam in World Politics (London: Routledge, 2005).

${ }^{39}$ Giora Eliraz, Islam in Indonesia: Modernism, Radicalism, and the Middle East Dimension (Brighton, Portland: Sussex Academic Press, 2004).

40 Saiful Mujani and R. William Liddle, "Politics, Islam and Public Opinion: Indonesia's Approaching Elections," Journal of Democracy, 15, 1 (2004), p. 117.

41 Ibid.

${ }^{42}$ Hefner, "Islam in an Era of Nation-State," p. 50.

${ }^{43}$ Ibid.

${ }^{44}$ Eliraz, Islam in Indonesia, p. 12.
} 
It is within this remarkable engagement with the ideas of democratic and pluralism that this Muslim group has played a prominent role in accepting and supporting Pancasila as the final foundation of Indonesia's nationhood and its political implications, especially with regard to the non-sectarian and harmonious relations between the various faiths. ${ }^{45}$ In the post-Soeharto era, civil or liberal Muslim group and their descendants seems to enhance further their strength and influences by holding many key positions in government and civil society. They are responsible in various ways for wide opposition to state enforcement of shari $x_{\text {ab. }}{ }^{46}$

The post-New Order Indonesia, however, has not only seen the continuing strength of liberal and progressive orientation of Islamic thinking and movement. A more ideological, political, literal and violent expression of Islam have also made their way into a more open political and public sphere. While at constitutional and political level, the attempt to establish the formal link between state and shari ath has once again failed to attract sufficient popular support, the struggle for shari $>h$ is still far from over. Given the minimum political support for inclusion of shari ath provisions into the constitution, the struggle for shari $>$ a continues with the focus "no longer on how to bring Islam into the foundation of the state, but how to bring Islamic coloration into policies produced by the state". ${ }^{47}$

The rise of more formalistic and exclusive Islamic discourse and groups has forced the younger liberal and progressive Muslim intellectuals to voice their liberal religious and political discourse in a more public and organized way. In January 2001, a number of younger Muslim intellectuals formed an intellectual network linking "different intellectuals and activists concerned with liberal interpretations of Islamic teachings to counter the fundamentalist discourse and movement". ${ }^{48}$ The term of 'Liberal Islam Network' or Jaringan Islam

\footnotetext{
${ }^{45}$ Emanuel Sivan, “The Clash within Islam," Survival, 45, 1 (Spring 2003), pp. 25-44.

${ }^{46}$ Mujani and Liddle, "Politics, Islam and Public Opinion," pp. 109-123.

47 Anies Rasyid Baswedan, "Political Islam in Indonesia: Present and Future Trajectory", Asian Survey, Vol. 44, No. 5 (September/October 2004), p. 669

${ }^{48}$ Muhamad Ali, "The Rise of JIL in Contemporary Indonesia", The American Journal of Islamic Social Sciences, 22, 1, p. 4
} 
Liberal (JIL) was then deliberately picked up as the formal name of the network. ${ }^{49}$

There was a lively internal debate among JIL activists and supporters over the meaning of "liberal Islam", particularly regarding what liberal should imply. At some points, it was clear that their understanding of terms such as "liberal" "left", and "conservative" is relative, and differs from the understanding of many non-Indonesians as well as their critics in Indonesia..$^{50}$ Some of them suggested, for example, that "liberal" must be differentiated from "liberalism" in the sense that in Western thinking, liberalism is often identified with the right, whereas in the discourse of Islamic thinking liberal Islam is associated with movements of the left. ${ }^{51}$

While different interpretations of 'liberal Islam' remain to exist, JIL activists eventually seemed to agree on the spirit of freedom of thought and expression. ${ }^{52}$ They read and were inspired by Kurzman's Liberal Islam: A Source Book, in which he uses liberal Islam to refer to basic themes in the history of liberalism, such as democracy, freedom of thought, social equality and human progress..$^{53}$ While they might be also familiar with Leonard Binder' Islamic Liberalism (1988), JIL activists, according to Ali, seems to be inspired more by Kurzman than by Binder while defining and formulating liberal Islam. ${ }^{54}$

\footnotetext{
49 Ibid., p. 5.

${ }^{50}$ Virginia Hooker, "Developing Islamic Arguments for Change through 'Liberal Islam'," in Virginia Hooker and Amin Saikal (eds), Islamic Perspectives on the New Millenium (Singapore: Institute of Southeast Asian Studies, 2004), p. 236.

51 Ibid.

52 Ali, 'The Rise of JIL in Contemporary Indonesia', p. 4.

${ }^{53}$ In his introduction, Kurzman traces the historical development of liberal Islam within two centuries long tradition of socio-religious interpretation in the Islamic world, defining liberal Islam as tradition of interpretation critical of two previously dominant traditions: customary and revivalist Islam. He further divides liberal Islam into three different modes: "liberal shari sh", "silent shari See Charles Kurzman, Liberal Islam: A Source Book (New York: Oxford University Press,1998), p. 4-5.

${ }^{54}$ Muhamad Ali, 5. Quite different from Kurzman, Binder uses the term "Islamic liberalism" or "liberal Islam" interchangeably in the political context and define them rather loosely. For him, all traditions in the interpretation of Islam, which is based on human reasoning or rational discourse, can be labelled Islamic liberalism. In the context of Middle East politics, he differenciates between Islamic liberalism, which argues that the idea of a liberal Islamic state is possible and desirable not only because
} 
Certain liberal political discourses are clearly formulated and promoted by JIL activists. JIL, for example, considers matter of being religious or being not religious as a personal right that should be protected by the state. Moreover, JIL believes in the separation of religious power and political authority. In a way that is similar, although not identical, to a kind of political liberalism as conceptualized by Rawls, JIL activists believe that religion functions in private and individual spaces. With regard to public affairs, they argue for a "collective ijtihad" process, when everyone can debate and every truth is determined inductively through the fit and proper test of vision. ${ }^{55}$

JIL's political ideas and discourses clearly have strong roots in political discourses popularized and promoted by the older generation of liberal and progressive Muslims since the 1970s and 1980s. Their more expressive and deliberate use of liberal political idioms and their more persistent discourse about "rethinking Islam" with liberal interpretations, however, has invited harsher criticism and opposition, mostly from emerging 'Islamist' and 'radical' groups. The latter groups harshly accuse JIL of deviating from Islamic principles for their consistent opposition to conventional interpretations of sharizh and attempts at attaining a more public position for political Islam in Indonesia. ${ }^{56}$

The criticism and unwelcome response, however, also come from certain factions of the mainstream moderate Islamic groups such as NU and Muhammadiyah. While remain generally regarded as the backbone of Islamic moderation in the country, NU and Muhammadiyah contain within them increasingly fragmented

such a liberal, democratic state accords with the spirit of Islam, but especially because Islam has few specific requirements or guidance on this issue, and "scripturalist liberalism" which justifies liberal institutions based on "explicit Islamic legislation of divine origin," not on liberal political, epistemological and moral principles. See Leonard Binder, Islamic Liberalism: A Critique of Development Ideologies (Chicago, London: the University of Chicago Press, 1988), pp. 243-4.

55 Nurdin, "Islam and State", p. 35

56 Timothy P. Daniels, 'Liberals, Moderates and Jihadists: Protecting Danish Cartoons in Indonesia', Contemporary Islam, 1, 1 (October 2007), pp. 240-1. For a further account on intellectual and discursive contestation between "liberal Islam" and "anti-liberal Islam" in Indonesia, see Akh Muzzaki, "Current Debate in the Post-Soeharto Indonesian Islam: Examining the Intellectual Base of Liberal and Anti-Liberal Islamic Movement," Al-Jami'ah, 45, 2 (2007), pp. 322-366. 
constituencies as manifested in their competing response towards liberal religious discourses. ${ }^{57}$ Within NU, for example, ideas such as secularism, liberalism, and pluralism have recently come under attack. Similarly, Muhammadiyah has recently experienced internal tensions between those espousing some liberal notions and those staunchly committed to shari ath-oriented perspective..$^{58}$

It is clear then that liberalism is still highly contested and its blending with Islamic discourse has been met by conflicting responses among different Muslim groups in Indonesia. It does not mean, however, that liberal Islamic discourse is becoming marginalized or losing its ground. Liberal Islamic discourse in one way or another had probably been a more powerful, if not hegemonic, discourse in Indonesia since the 1970s until late 1990s. Yet, despite the rise of the rivalling radical and literal Islamic discourses in the aftermath of Soeharto era, it continues to be an influential intellectual movement in the country.

Assyaukanie, a leading JIL's activists, affirms this continuing importance of liberal Islamic thinking by suggesting that secularization, which during the 1970s was condemned, is now becoming a central theme in the current political debates among the younger generation of santri Muslims. ${ }^{59} \mathrm{He}$ even goes further by confirming and at the same time refining Harry J. Benda's thesis on history of Indonesia. While Benda, in the 1950s, predicted that the history of Indonesia is the extension of santri civilization, Assyaukanie contends that "the history of Indonesia is the expansion of liberal and progressive santri civilization". ${ }^{60}$ The fact that various attempts to establish a more formal link between Islam or shari $x h$ and state has been lacking a unified political and popular support could be partly attributed to the strength of democratic and liberal voice in the country. This does not

${ }^{57}$ Ibid., p. 240.

58 See Timothy P. Daniels, 241. For a more detailed account of NU and Muhammadiyah response to liberalism, especially, following the recent fatwa prohibiting pluralism, secularism and liberalism by Majelis Ulama Indonesia (MUI) or Council of Indonesian Ulama, see Pier Gillespie, 'Current Issues in Indonesian Islam: Analysing the 2005 Council of Indonesian Ulama Fatwa No. 7 Opposing Pluralism, Liberalism and Secularism' Journal of Islamic Studies, 18, 2 (2007), pp. 202-240.

${ }^{59}$ Luthfi Assyaukanie, Islam and the Secular State in Indonesia (Singapore: Institute for Southeast Asian Studies, 2009), p. 230.

${ }^{60}$ Ibid., p. 231. 
necessarily means, however, that there is no signs or trends of the contrary.

What is important to note here, however, is that although democratic and liberal in character, the political discourse forged by liberal Muslims is not merely, and not always, derivative of Western liberalism. As noted by Hefner, some of the emphases of contemporary civil or liberal Islam in Indonesia show a different mix of ideas and themes than those of contemporary liberals in the secular West. ${ }^{61}$ For Hefner, in its emphasis on public virtue and justice, for example, civil or liberal Islam is much closer to the traditions of civic republicanism rather than secular liberalism. ${ }^{62}$ Thus in a broader term, liberal Islamic discourse in Indonesia represents more a strong support for Jose Casanova's thesis that religious movements can be progressive, inclusive and actively engaged in the public discourse whilst at the same time supporting secular liberal democracy. ${ }^{63}$

It is in this sense that the support for 'political liberalism' in Indonesia developed without necessarily following Rawlsian 'liberal' public reason. As observed by Bowen, religious reasoning and arguments have been strongly influential in the political discourse of liberal Muslim in Indonesia. ${ }^{64}$ The political debates often involve and invoke Islamic terms in efforts to interpret religious texts in such a way that are compatible with other doctrines, including liberal ones. More importantly, the reasoning of liberal and progressive ideas rooted in an Islamic context and anchored in Islamic beliefs has been partly responsible for their growing support. ${ }^{65}$ In these instances, Indonesian liberal Muslims endorse, not a political conception of justice as in Rawls, but, as Bowen puts it, "a reasonable conception of justice that is public and also Islamic." 66

\footnotetext{
${ }^{61}$ Hefner, Civil Islam, p. 190.

62 Ibid., p. 191.

${ }^{63}$ See Jose Casanova, Public Religion in the Modern World (London: The University of Chicago Press, 1994).

${ }^{64}$ John R. Bowen, Islam, Law and Equality: An Atbropology of Public Reasoning (Cambridge: Cambridge University Press, 2003), p. 265.

${ }^{65}$ Eliraz, Islam in Indonesia, p. 284

${ }^{66}$ Bowen, Islam, Law and Equality, p. 265
} 


\section{Conclusion}

This paper has shown that a more nuanced understanding of Islam and liberalism is needed in order to avoid essentialized accounts on the contingent, complex relationship between the two. Understanding Islam, like any other religion, as multivocal entity is certainly important, but this should also be accompanied by an awareness of the working of certain power relation within a distinctively Islamic discursive tradition that renders particular discourse acceptable, dominant or hegemonic. Talal Asad's idea of Islam as 'a discursive tradition' is particularly important in this respect.

On the other hand, important development in contemporary liberalism such as the distinction between its comprehensive nature and its more limited political conception as elaborated by John Rawls also merits further scrutiny in the discussion on Islam and liberalism. Rawls' conceptualization of political liberalism in particular can be critically deployed in examining the degree to which Muslims have accepted certain kind of liberal political premises in developing a democratic political order, without necessarily pushing religion and religious reason into a limited private sphere.

Reviewing the evolving relationship between Islam and liberalism in Indonesia, the paper has also shown that liberal political discourse has a strong resonance among major Islamic groups. The support of the state 'neutrality' and the opposition to the imposition of shari axb by the state, in particular, has been widely and continuesly supported, although by no means it has settled once for all and without some signs of the contrary. It could be argued that there has been a growing support for what is similar, but not identical, to Rawlsian political liberalism. The way Indonesian liberal and moderate Muslims develop and support an 'overlapping consensus', however, does not match Rawlsian liberal notion of political conception of justice and public reason. Instead of a purely liberal political conception of justice and public reason, what is growing and gaining support for some time in Indonesia is a conception of justice which combines Islamic and democratic ideals. [] 


\section{Bibliography}

\section{Books and Articles}

Al-Azmeh, Aziz. Islams and Modernities. London, New York: Verso, 1993.

Ali, Muhamad. "The Rise of JIL in Contemporary Indonesia." The American Journal of Islamic Social Sciences, 22: 1.

Anderson, John. "Does God Matter, and If So Whose God, Religion and Democratization." Democratization, 14, 4, August 2007.

An-Na'im, Abdullahi Ahmed. Islam and the Secular State: Negotiating the Future of Shari'a. Cambridge, Mass: Harvard University Press, 2008.

Anjum, Ovamir. "Islam as A Discursive Tradition: Talal Asad and His Interlocutors." Comparative Studies of South Asia, Africa and the Middle East. 27, 3, 2007.

Asad, Talal. "Ideology, Class and the Origin of the Islamic State." Economy and Society. 9, 4, November 1983.

-------. The Idea of Anthropology of Islam. Occasional Paper Series Washington D.C: Georgetown University Centre for Contemporary Arab Studies, 1986.

------. Formation of Secular: Christianity, Islam, Modernity. Stanford: Stanford University Press, 2003.

Assyaukanie, Luthfi. Islam and the Secular State in Indonesia. Singapore: Institute of Southeast Asian Studies, 2009.

Azra, Azyumardy. "Globalization of Indonesian Muslim Discourse: Contemporary Religio-Intellectual Connection Between Indonesia and the Middle East." in Johan Meuleman (ed.). Islam in the Era of Globalization. London: RoutledgeCurzon, 2002.

Bahlul, Raja. "Toward Islamic Conception of Public Reason." Critique: Critical Middle Eastern. 12, 1 Spring, 2003.

Barton, Greg. "The Impact of Neo-Modernism on Indonesian Islamic Thought: The Emergence of a New Pluralism." in David Bourchier and John Legge (eds.). Democracy in Indonesia: 1950s and 1990s. Clayton: Centre of Southeast Asian Studies, Monash University, 1996. 
Bayat, Asef. Making Islam Democratic: Social Movements and the Post-Islamist Turn. Stanford, California: Stanford University Press, 2007.

Beydoun, Khaled A. "Laicite, Liberalism and the Headscarf." Journal of Islamic Law and Culture. 10, 2, 2008.

Bilgin, Mehmet Fevzi. "The Prospect for Political Liberalism in NonWestern Societies." Critical Review of International Social and Political Philosophy. 10, 3, September 2007.

Binder, Leonard. Islamic Liberalism: A Critique of Development Ideologies. Chicago and London: Chicago University Press, 1988.

Bowen, John R. Islam, Law and Equality: The Anthropology of Public Reasoning. Cambridge: Cambridge University Press, 2003.

Casanova, Jose. Public Religion in the Modern World. London: The University of Chicago Press, 1994.

Daniels, Timothy P. "Liberals, Moderates and Jihadists: Protecting Danish Cartoons in Indonesia." Contemporary Islam. 1, October 2007.

El-Fadl, Khaled Abou. "The Orphan of Modernity and the Clash of Civilizations." Global Dialogue. 4, 2, Spring 2002.

Eliraz, Giora. Islam in Indonesia: Modernism, Radicalism, and The Middle East Dimension. Brighton; Portland: Sussex Academic Press, 2004.

Esposito, John L and John A. Voll. Islam and Democracy. New York and Oxford, 1996.

Fadel, Mohammad. "The True, the Good and the Reasonable: the Theological and Ethical Roots of Public Reason in Islamic Law." Research Paper, University of Toronto Legal Studies Series. 2007.

Fealy, Greg and Greg Barton (eds.). Nahdlatul Ulama, Traditional Islam and Modernity in Indonesia. Clayton: Monash Asia Institute, Monash University, 1996.

Fealy, Greg. "Islamisation and Politics in Southeast Asia: the Constrasting Cases of Malaysia and Indonesia." in Nelly Laboud and Anthony H. Johns (eds.). Islam in World Politics. London: Routledge, 2005. 
Fukuyama, Francis. "History and September 11." in Ken Booth and Tim Dunne (eds.). Worlds in Collision: Terror and the Future of Global Order. New York: Palgrave McMillan, 2002.

Gelner, Ernest. Conditions of Liberty: Civil Society and Its Rivals. London: Verso, 1994.

Gillespie, Piers "Current Issues in Indonesian Islam: Analysing the 2005 Council of Indonesian Ulama Fatwa No. 7 Opposing Pluralism, Liberalism and Secularism." Journal of Islamic Studies. 18, 2 (2007): pp. 202-240.

Halliday, Fred. Islam and the Myth of Confrontation: Religion and Politics in the Middle East. London: IB Tauris, 2003.

Hefner, Robert W. and Patricia Horvatich (eds.). Islam in An Era of Nation-State: Politics and Religious Renewal in Muslim Southeast Asia. Honolulu: University of Hawaii Press, 1997.

-------. Civil Islam: Muslims and Democratization in Indonesia. Princeton and Oxford: Princeton University Press, 2000.

--------. Remaking Muslim Politics. Princenton: Princeton University Press, 2005.

Hooker, Virginia "Developing Islamic Arguments for Change through 'Liberal Islam'.' in Virginia Hooker and Amin Saikal (eds.). Islamic Perspectives on the New Millenium. Singapura: Institute of Southeast Asian Studies, 2004.

Huntington, Samuel P. The Clash of Civilizations and the Remaking of World Order. New York: Simon and Schuster, 1996.

Ismail, Salwa. Rethinking Islamist Politics, Culture, the State and Islamism. London: IB Tauris, 2003.

Kurzman, Charles. Liberal Islam: A Source Book. New York: Oxford University Press, 1998.

Lewis, Bernard. "The Roots of Muslim Rage: Why so many Muslims deeply resent the West, and why their bitterness will not easily be mollified." Atlantic Monthly. September 1990.

March, Andrew F. "The Demands of Citizenship: Translating Political Liberalism into the Language of Islam." Journal of Muslim Minority Affairs. 25, 3, December 2005. 
". "Reading Tariq Ramadan: Political Liberalism, Islam, and 'Overlapping Consensus'." Ethics \& International Affairs, 21, 4, Winter 2007

McLoughlin, Sean. "Islam(s) in Context: Orientalism and the Anthropology of Muslim societies and cultures." Journal of Beliefs \& V alues. 28, 3, December 2007.

Mujani, Saiful and R. William Liddle, "Politics, Islam and Public Opinion: Indonesia's Approaching Elections." Journal of Democracy. 15, 1, (2004): pp. 109-123.

Muzzaki, Akh "Current Debate in the Post-Soeharto Indonesian Islam: Examining the Intellectual Base of Liberal and Anti-Liberal Islamic Movement." Al-Jami'ah. 45, 2, (2007): pp. 322-366.

Nurdin, M. Ali. "Islam and State: A Study of the Liberal Islamic Network in Indonesia, 1999-2004." New Zealand Journal of Asian Studies. 7, 2 December, 2005.

Parekh, Bikhu. Rethinking Multiculturalism: Cultural Diversity and Political Theory. Basingstoke: Macmillan, 2000.

Rawls, John. Political Liberalism. expanded edition. New York: Columbia University Press, 2005.

Saeed, Abdullah. "Ijtihad and Innovation in Neo-Modernist Islamic Thought in Indonesia." Islam and Christian-Muslim Relations. 8, 3, (1997): pp. 279-295.

Said, Edward. "Scholars, Media and the Middle East." in G. Viswanathan (ed.). Power, Politics, and Culture: Interviews with Edward Said. New York: 2001.

Sajoo, Amyn B. "Introduction: Civic Quest and Bequests." in Amyn B. Sojo (ed.). Civil Society in the Muslim World: Contemporary Perspectives. London: IB Tauris, 2003.

Sivan, Emanuel. "The Clash within Islam.” Survival. 45, 1 (Spring 2003): pp. 25-44.

Stepan, Alfred. " Religion, Democracy and 'Twin Toleration'." Journal of Democracy. 11, 4, October 2000.

Stout, Jeffrey. Democracy and Tradition. Princeton: Princeton University Press, 2004. 